\title{
REMOVAL OF CRUSADERS FROM THE EASTERN MEDITERRANEAN IN THE MAMLUK-CRUSADER STRUGGLE
}

\author{
Altan Çetin \\ Anadolu University, Art Faculty, History Departmant \\ altanoides@yahoo.com
}

\begin{abstract}
One of the most important issues facing the Mamluk State since its establishment was to continue the struggle with the Crusaders who settled in the region. In fact, after the failure of the 3rd Crusade, Egypt became the new strategic target of the Crusaders under the Ayyubid administration. The developments that started during the reign of Sultan Baybars continued in the period of Kalavun and al-Eshref until the conquest of Akka. From this point on, ez-Zâhir Baybars marched at the head of a large army at the beginning of February 1265 and took over the cities of Kaysariyye, Yafa, Aslis, and Arsuf. In the summer of 1266, he tookover Safad and er-Remle. It caused a heavy blow to Armenia Minor. In 1267, Sultan Baybars looted the districts of Taberiyye and Akkâ and invaded the cities of Jaffa, es-Shakif, and Arnun the following year. Finally, he crowned the invasion wars against the Crusaders with the conquest of Antioch (April 1268). Baybars' conquering of Antioch has been marked by contradictions. However, he will eliminate the crusader presence in Antioch and its surrounding by various methods and occupy the areas in the north of Syria, and finally narrow the area of the Crusader activity. It is an extremely important event that Antioch was conquered by Muslims in 1268. Because Antioch is the second principality established by the Crusaders in the East (1097) after Urfa, and the capture of this place is a piece of new evidence that the great structure that the Crusaders set up in Syria towards the end of the 11th century began to collapse. This eliminated the presence of crusaders on the shores of the eastern Mediterranean, where they could indeed dominate until the First
\end{abstract}


Crusade, and their withdrawal from the eastern Mediterranean is shown here. The struggle that took place in the period after Sultan Baybars and later, resulted in the fact that the defense against the Crusader attacks was first poured into the Mediterranean and then they were completely removed from there. The great Crusader attack in the 14th century spread over a century from different fronts and took place through the Balkans, the Aegean, and the Eastern Mediterranean. After the Crusaders' main body was removed from Syria, the Armenian and Cypriot structures, which were their deputies, were also eliminated in the following periods. The Mamluks caused great losses to the Crusaders and their allies in the Eastern Mediterranean during the last period of the Crusades. This article examines how the Crusader presence was eliminated by the Mamluks in Antioch, Çukurova, and Cyprus.

Keywords: Mamluks, Egypt, Antioch, Cyprus, Armenian Barony

Apstrakt: Jedno od najvažnijih pitanja s kojima se država Memluk suočila od njenog osnivanja bila je borba s križarima koji su se naselili u regiji. Nakon neuspjeha Trećeg križarskog rata, Egipat je postao nova strateška meta križara pod upravom Ajubida. Dešavanja započeta tokom vladavine sultana Baybarsa nastavila su se razvijati tokom perioda Kalavuna i al-Eshrefa sve do osvajanja Akke. Nakon tog događaja, ez-Zâhir Baybars zajedno s velikom vojskom početkom februara 1265. godine zauzeo je gradove Kaysariyye, Yafa, Aslis i Arsuf. U ljeto 1266. godine preuzeo je Safad i er-Remle, te je tako zadao težak udarac Maloj Jermeniji. Sultan Baybars je 1267. godine opljačkao okruge Taberiyye i Akkâ, a sljedeće godine napao gradove Jaffa, es-Shakif i Arnun. Konačno, invazijske ratove protiv križara okrunio je osvajanjem Antiohije (april 1268). Baybarsovo osvajanje Antiohije i širenja njegove dominacije u regiji obilježeno je kontradiktornostima. Međutim, to ga nije spriječilo, da različitim metodama, nastavi borbu protiv križara, zauzme tvrđavu Antiohiju i okolicu. Zauzevši prolazno područje na sjeveru Sirije značajno je suzio područje djelovanja križara. Osvajanje Antiohije od strane muslimana 1268. godine izuzetno je važan događaj s obzirom da je Antiohija bila druga kneževina koju su nakon Urfe osnovali križari na Istoku (1097). Zauzimanje ovog mjesta bila je potvrda da se velika tvorevina koju su križari uspostavili u Siriji krajem 11. vijeka počela urušavati. Time je eliminisano prisustvo križara na obalama istočnog Mediterana gdje su zaista dominirali nakon Prvog križarskog rata. Proces njihovog nestajanja na istočnom Mediteranu detaljno je prikazano u ovom članku. Borba koja 
se odvijala u periodu nakon sultana Baybarsa, rezultirala je proširenjem odbrane od napada križara na Mediteran odakle su zatim u potpunosti potisnuti. Veliki križarski napad tokom cijelog 14 . stoljeća proširio se na različite frontove i razvio se preko Balkana, Egejskog mora i istočnog Mediterana. Nakon što je glavnina trupa križara uklonjena iz Sirije, armenske i ciparske strukture, koje su bili njihovi zamjenici, također su eliminirane u narednom periodu. Memluci su nanijeli velike gubitke križarima i njihovim saveznicima na istočnom Mediteranu tokom posljednjeg perioda križarskih ratova. Ovaj članak ukazuje na koji su način Memluci eliminirali prisustvo križara u Antiohiji, Čukurovoj i na Kipru.

Ključne riječi: Memluci, Egipat, Antiohija, Kipar, jermenska baronija

\section{Introduction}

Inconceivable dynamics and structure of geography regarding the historical process condemn those who do not take lessons from them to a life of misery and continuous upheaval. On the contrary, those who are "literate" can become the exception. Anatolia, Syria, and Egypt; three landmasses that encompass the Eastern Mediterranean. Cyprus, right in the middle of this frame as a strategic bridge. One of the unchanging staging points for those who would like to threaten these lands. All three territories have experienced attacks throughout history from both east and west. An interesting point is that there is a historical pattern and we are a part of it.

One can easily acknowledge the geostrategic facts when looking at the Crusades; one of the most prominent incidents echoing through the Middle Ages. It is known that the First Crusade started in Anatolia. Their so-called aim was Jerusalem. It was to hide the military and political intervention under an aesthetical religious cloak. The main reason was to establish dominion across the land and to exploit it. After three Crusades, Europeans of that time saw that they can't gain anything from this land, which they called "Turkey", and set their scopes to Acre and Syria, reachable from the sea. The fall of Jerusalem to the Muslim hand was a pivotal incident in 1187, as it gave the upper hand to the Turks to block the land-bound 
Anatolian approach, so the sea routes were more preferable. One of these Crusades (3rd) saw English King Richard the Lionheart seize Cyprus from its Byzantine overlords en-route to reinforce Jerusalem. Then the focus of campaigns shifted from Seljuk Anatolia to Ayyubid, and then Mamelukan Syria and Egypt. The Crusaders of Syria, out of hope, attacked Egypt under the leadership of French King Louis in 1254.

As can be seen, all the coasts and lands bound to the Eastern Mediterranean were gradually affected by the attack. This strategy about the Eastern Mediterranean, created by the Crusades, will be repeated later due to the region's unchanging geopolitics and economy. At the time, strong military and political forces inside Seljuks, Ayyubids, and Mamluks would void these attacks and expel the Crusader presence from the entire area. However, the historical background created a strategical mind, repeating itself. Power structures, context, and tensions gave an advantage to regional powers and/ or outsiders as the wind blew. This article is written to take a retrospective look into the geography with its set and changing structures from a historical scope and to create an opinion over the matter.

Seen as the classical age of the crusades, the 13th, 14th, and even 15th centuries saw the battle between the Mamluks and the Crusaders. Attacks spanning long centuries were often braced by Turkish states and leaders of the Muslim lands. This evaluation is not a mere interpretation but a fact written by Arabic Muhibeddin Abū Hâmīd Maqdisī, who was a contemporary figure of the Mamlukean Cairo and the era. We can see this inside Abū Hâmìd's work Merits of Mamluk Turks", the chapter entitled "On The Blessings Bestowed to Turks, and to All Muslims through them being on this land. "Some things appeared to me, that were not apparent to other people, and the first one is the greatest. Turks are those who perform the duty of Jihad for the Muslims in our times and those who fight against Tatars (Mongols) Franks (Crusaders), against rebels to Imam (Leader) of Muslims appointed by Allah, and against those who wish to invade Muslim lands and destroyed all of them; and also conquered Frank lands and 
beaches on the borders. They are those who conducted the holy mission of Jihad since they had come to these lands." It is clearly stated that the coastline was cleared from the Crusaders by the Turks. This article will try to illuminate the events of the Mamluk- Crusaders struggle over the Eastern Mediterranean in the light of sources and to elevate the facts set by the framework Abū Hâmīd constructed.

It started in the late 11th century, the Crusades gave a new shape to the East-West relations. It is known that the Crusaders had many plans in their minds regarding the Egyptian Mamluks, which played a significant role in Muslims eventually keeping the Holy Lands under control in spite of the great bloodshed and struggle. One of those plans was to destroy them with an economic blockade. To achieve this, they had to cut off the supplies coming from Europe to Egypt, to prevent them getting slaves to bolster the army, and to cut the tariff income of eastern goods sold to Europe from the Alexandria Port, which were imported from India and stored there. So the Papacy set strict trade rules for the Mediterranean. The ships that sailed to and from East were frequently checked. Regardless of the proportion of illegal sea trade, Egypt was still harmed. ${ }^{2}$ Also with Acre and other Crusader strongholds over the Syrian coastline conquered by the Muslims in 1291 and the final expulsion of the Crusaders from the land affected the Egypt-European trade drastically. The monks were keen to end all trade operations. Pope Nicholas IV forbid all trade for goods related to weaponry, logs, etc. to the Muslims. His successors followed suit. But the trade ban was hard to continue. Trade was far more important than the religious motives for the Frank traders. The efforts of the Egyptian rulers to facilitate and develop trade attracted them to this country. Europeans needed the spices and other goods from India, so as Mamluks needed European gold

${ }^{1}$ Muhibeddin Ebu Hamīd Makdīsī, Türk Memlüklerin Faziletleri, (Translated into Turkish by Ramazan Şeşen), Istanbul: Yeditepe Publications, 2019, 83.

${ }^{2}$ Mustafa Akdağ, Türkiye’nin İktisadi ve İçtimâ̂ Tarihi, vol. 1, Istanbul: Cem Publications, 1995, 351; Mustafa Safran, "13. Ve 14. Yüzyıllarda Karadeniz Limanlarının Ticarî ve Tarihi Önemi”, Ondokuz Mayıs Üniversitesi, Eğitim Fakültesi Birinci Tarih Boyunca Karadeniz Kongresi Bildirileri, Samsun: Ondokuz Mayıs University Press, 1988, 459. 
and weapons. Both European and Mamluk traders had strong incentives. The Papacy tried excommunication and armed prevention but to no avail, it had to lift the bans except on weaponry. ${ }^{3}$ In response to this attitude of the West, the goal of the Mamluk Sultans was to weaken the Crusader States, to crush them as much as possible and to resist the Western powers that could come to help the Crusader States in Syria. Therefore, they have established friendly relations with some Western princes. They tried to assess the political situation in Europe and what might become reality in near future 4 Trade continued during the Crusades and the Mamluks made pacts with the Crusaders. For instance, Sultan al-Zāhir Rukn al-Dīn Baybars had a deal with Kendeyafa, ruler of Beyrouth. Pacts were signed with Beyrouth in 1268 and with the Hospitaller Knights in 1269. Sultan al-Manșūr Sayf al-Dīn Qalāwūn (1280- 1290) followed Sultan Baybars' way of dealings. Pacts were signed with the rulers of Acre and Tripoli in 1281. The Black Sea route was secured with an agreement with Byzantine in 1282. Qalāwūn allied with the ruler of Tyre in $1285 .{ }^{5}$ Europeans were trying to subdue Mamluks by blockades and to exploit the Byzantine Empire by concession agreements. ${ }^{6}$ But the pen and diplomacy were working even under the shadow of the swords. Whilst the struggle to lift the Papacy ban continued as explained, any opportunities to take up arms and fight the Crusader stronghold were also being taken.

One of the most imminent threats to the Mamluks since the establishment of the state was the Crusaders that settled throughout the region, so their priority was to continue the fight. In fact, after the failure of the $3 \mathrm{rd}$

\footnotetext{
${ }^{3}$ İsmail Yiğit, "Memlûkler”, Siyasî, Dini, Kültürel, Sosyal İslâm Tarihi, vol. 7, 1991, İstanbul: Kayıhan Publications, 233; Tawfiq al-Yûzbekî, Tarihu Ticara Misr al-Bahrîyya fi Asri'l Mamâlîk, Mosul: Matbaatü'l-İ̀şad, 1975, 62-63; Hatim Abdurrahman Tahavi, "al-Șalibiyyun; Safahat min Naşat İktisadiyya”, İctihat, vol. 33, Dimask: Dāru'l-İctihad, 1996, 101.

${ }^{4}$ Wilhelm Heyd, Yakın-Doğu Ticaret Tarihi (Ter. Enver Ziya Karal), Ankara: Türk Tarih Kurumu Basımevi, 1975, 476.

${ }^{5}$ Ahmad Muhammad Muhammad Advan, al-Vadıa al-İktisadiyya fi Misr fi Asri'l-Mamlûkiyya al-'Ula, Cairo, 1972, 388-389. (Unpublished Phd Thesis).

${ }^{6}$ M. Akdağ, Türkiye’nin İktisadi ve İçtimâ̂ Tarihi, 351.
} 
Crusade in Egypt, it became the new strategic target of the Crusaders under Ayyubid rule. Events started during Sultan Baybars' reign continued into Qalāwūn and Sultan al-Ashraf's years, finally escalating to the conquest of Acre. Al-Zāhir Baybars began a campaign in February of 1265, leading a huge army and annexing Caesarea, Jafa, Aslis, and Arsuf. Safad and ar-Ramla fell in the summer of 1266. Armenia Minor has experienced a huge defeat. Baybars raided Taberiyya and Acre countrysides in 1267, and conquered al-Shaqif / Beaufort, Jafa, and Arnun the next year. Finally, he crowned the campaign with the conquest of Antioch (April 1268). Bounties from Antioch were so plentiful that they were shared between aces. The conquest of Antioch by the Muslims in 1268 is an important event. It was the second Crusaders' Princedom after Odessa and the fall of Antioch was signaling that the great structure built in Syria by the Crusaders was crumbling in the late 11 th century.

\section{The Fall of Antioch Crusader Principality During Mamluk-Crusader Struggle in the Eastern Mediterranean}

When analyzing the Mamluk-Crusaders relations which span throughout a wide time frame, conquests of Antioch, Çukurova, and Cyprus following the defeats of the Principality of Antioch, Armenian Kingdom, and the Cypriot Crusader Kingdom and the ensuing dismantlement of their immediate legacies became prominent. The Mamluks wiped out almost everything regarding the Crusaders inside the Eastern Mediterranean crescent over time. The Islamic World, shaken by the First Crusade immediately got on their feet to fight against the new status quo, and the final blow was dealt by the Mamluks. The Mamluk era also signifies the end of the Classical Crusades era. After the First Crusade, Antioch and Odessa emerged as the main powerhouses to threaten Syria. The fall of Odessa to Imadeddin Zangi was the first victory of the Islamic World and it symbolized the cooperation and peace between Islamic Powers. On this legacy of unity, Nūr al-Dīn Mahmud brought Egypt into the fold and after Salah al-Dīn 
Ayyubid's conquest of Jerusalem, the Crusaders were dealt a huge blow and their area of control was stuck to a narrow coastline.

\section{General Diplomacy of Sultan Baybars}

After the initial conquests, the Mamluks rose from this legacy and wiped out the last Crusader bastions of Antioch and Tripoli. Antioch was doomed because of the brilliant diplomacy led by Sultan Baybars over the region. An Arabic poet wrote about him: "O' Turkish lion and their pillar! $\mathrm{O}$ ' avenger after fear and despair! You defeated the rampant and brought us peace. You crossed the Euphrates and reached Caliphate,"7 to express this Turkish Sultan's achievements. In addition to his great campaigns against the Crusaders and the Mamluks, Baybars also created unity inside. As Baybars continued the fight against the Crusaders which he inherited from the Ayyubids and their respective predecessors, there is no doubt that the Crusaders of the region were giving information to the Mongols to encourage them against the Muslims. The same situation can also be seen during the campaign against the Armenians. To summarize it, we can state that the struggle over Syria was complex in its nature because of this intertwining network of relations and events with the Crusaders and Mongols. These two powers coming together was a great threat to the Mamluks. Because of that, it is hard to separate the fight of Baybars against the Crusaders and Mongols from one another. In many cases, the Mamluk Sultan fought against them simultaneously. ${ }^{8}$ To carry on this battle against enemies hailing from both east and west of Euphrates, the Mamluks needed to hold strong in Bilād al-Shām. The Crusaders of Antioch favored the Mongols and there is no doubt that it shifted Baybars' opinion towards more enmity,

\footnotetext{
7 İbrahim Ethem Polat, «Arap Edebiyatı Üzerinden Türk Tarihine Bir Bakış”, available: http:// www.ayk.gov.tr/wp-content/uploads/2015/01/POLAT-\%C4\%B0brahim-Ethem-ARAP-EDEB\%C4\%B0YATI-\%C3\%9CZER\%C4\%B0NDEN-T\%C3\%9CRK-TAR\%C4\%B0H\%C4\%B0NE-B\%C4\%B0R-BAKI\%C5\%9E.pdf(06.08.2017), 327. (accessed: 6. 8. 2017)

${ }^{8}$ Cüneyt Kanat, «Baybars Zamanında Memlûk-İlhanlı Münasebetleri”, Tarih İncelemeleri Dergisi, vol. XVI, İzmir: Ege University Press, 2001, 32.
} 
and affected the campaigns. Baybars, who settled the Turkomans into the region, sought to establish unity within the kingdom and to end any problems within Syria before the fight against the Crusaders, Armenians and Mongols could begin, so his first moves regarding Syrian and al-Jazirean politics were aimed for this goal. The shrewd Sultan suppressed the rebellions of Syria, gathered the Naval Mamluks which were all over the region and beyond, took measures to strengthen his position inside the army ranks and to gain the loyalty of the army, and lastly, to cut down taxes to gain the favor of the public and the farmers. He also revived Abbasid Caliphate which was destroyed by Hulagu in Egypt to strengthen the Mamluk rule over the region. In addition, he took important steps in the Turkification process of the region with the campaigns he organized against the Armenians. ${ }^{9}$ The Mamluks finally crushed the Armenians in 1375, paving the road for the Turkification of the region.

Turkish dominion over Antioch dates back to Suleymanshah. The conquest of the city had been carried out by Kutalmisoglu Suleymanshah, who acted upon the plea of Ismail, the governor of the cruelly governed city under the Armenian Flaretos. Upon the conquest, Suleymanshah treated the people fairly, set the captives free, and forbid his soldiers from entering Christian houses and taking their women, even if it is for marriage. ${ }^{10}$ Melikshah appointed Yagisiyan, one of his household amirs to the government of the city. Until the Crusaders arrived, he governed the city in the name of Ridvan, Melik of Aleppo. When the Crusaders arrived on 21 October 1097, Yagisiyan was the amir of Antioch. The city withstood the siege till 3rd of June, 1098 but one of the governor's commanders, Firuz, betrayed him which resulted in the massacre inside the city upon the capture by the Crusaders. Genoese, who helped the siege got a bazaar, 30 or so houses, a chapel, and a fountain. The Crusaders established a princedom here

\footnotetext{
${ }^{9}$ Altan Çetin, "Memlükler Devrinde Oguzlar/ Türkmenlere Bir Bakış", Osmanlı Araştırmaları, vol. 33, İstanbul: İstanbul University Press, 2009, 24-25.

${ }^{10}$ Ali Sevim, Anadolu’nun Fethi-Selçuklular Dönemi, Ankara: Türk Tarih Kurumu Press, 2014, 107.
} 


\section{under Bohemund, the son of Robert Guiscard. ${ }^{11}$ Many Crusader dynasties ruled over the state till 1268. Antioch was one of the key elements after the}

11 "Principality of Antioch" (1098 - 1268): When the City of Anticoh was conquered by the Crusaders on 3rd of June, 1098, they didn't give the city to the Byzantine Emperor. Muslims were massacred and Bohemund established a Norman rule. But the friction between the Orthodox locals and the Crusaders grew even more when Bohemund brought a Latin- Catholic patriarch into the city. When Bohemund got captured by a Danismend Beg in August of 1100 his nephew Tancred became regent and he expanded his territory and took the important Byzantine port city of Latakia. Bohemund was set free in 1103 and after the defeat of Harran in 1104, he returned to Europe to convince Pope Pascalis II for another crusade. But he attacked the Byzantine city of Dyrrhakhion with the Crusader army instead of going to holy lands. Just like the campaign of 1081 , the attack was a failure, and he swore allegiancee to Emperor in 1108 as the King of Antioch. Then he returned to Italy and died in 1111. Tancred, who was the acting ruler of Antioch, disregarded his uncle's oath. Lordship and Patriarch authority over Antioch stayed a hot matter between the states. When Tancred died in December of 1112, his cousin Roger de Salern became a ruler. Norman rule over Antioch were dealt a huge blow with the battle of "Bloody Battle" (Ager Sanguinis = Ma'reketü sâhati'd-dem) against Necmeddin Ilgazi, the Beg of Artuqlu at 28th of June, 1119 at Tel Ifrin. Roger the Salerne died on the battlefield and King Baudouin the Second of Jaruselam took control until Bohemund II, son of Bohemund arrived. Bohemund II arrived in 1126 and married Alice, daughter of King Baudouin II but his era ended in 1130 when he was killed in a battle against Danishmendlis. His wife became regent for their daughter Constance but when she got married to Raimond de Poitiers in 1136, he was crowned. Raimond accepted Byzantine overlordship after Ioannes Komnenos' campaign of 1138. The Emperors' second campaign to Antioch in 1142 was a great threat but when he died in 1143, Raimond was saved from this incursion. The biggest threat to his rule was the Ruler of Aleppo, Nureddin Imadeddin Zangi because he had conquered Odessa and now was the time for Antioch. The loss of Odessa also ignited another Crusade over Europe. The Crusader host led by the French king Louis VII arrived in Antioch in 1148 but Raimond didn't get their help because they just wanted to carry on to Jerusalem. Shortly after, Raimond died in a battle against Zangī (1149). His wife Constance married Renaud de Chatillon. His reign ended when he got captured by Nur al-din in 1161. Bohemund III, son of Constance and her first husband Raimond was crowned. Principality of Antioch existed without much to say in Eastern politics, till the Mamluk Sultan Baybars I removed the state in 1268., Ișın Demirkent, "Haçlilar", D. F. I. A. (Diyanet Foundation Islamic Encyclopedia), vol. 14, Istanbul: Turkish Diyanet Foundation Publications, 1996, 531; Aydın Usta, Haçlı Seferlerinde Kuşatma, Istanbul: Yeditepe Publications, 2015, 77-95; al-Qalqashandī, Shihab al-Din Ahmad ibn 'Ali, Subh al-Ashā fi Sinäàt al-Inshā, Edited by Muhammad Husayn Shemseddin, vol. 4, Beirut: Dāru'l-Kutubu'l-İlmiyyah, 1987, 185; Fulcher of Chartes, The First Crusade, The Chronicle of Fulcher of Chartres and Other Sources Materials, (ed. by Edward Peters), Philadelphia: Penguin Classics, 1998, 202-204; Işın Demirkent, Haçlılar, D. F. İ. A, vol. 14, İstanbul: Turkish Diyanet Foundation Publications, 529530, 531; Özlem Genç, Harun Korunur, “Antakya 'nın Haçlılar Tarafından Ele Geçiriliși”, Studies of Ottoman Domain (Electronic Journal), vol. 6, 2016, 62. available: http://www.thestudiesofottomandomain.com (accessed: 6. 8. 2017) 
First Crusade, being a northern base to squeeze Syria and block Anatolian passage into the region.

\section{City of Antioch}

According to al-Qalqashandī, Antioch was the pinnacle example of the al- 'Awāșim (reinforced cities on Byzantine border) cities. It is an old and grand city on the Mediterranean coastline. It had a very large castle like no other in the world. It had fertile lands. Asi and Nahr al-Aswad rivers pass through it. ${ }^{12}$ Antioch was a subject to Aleppo, just like any northern border cities of the Mamluks. Al-Qalqashandi counted them as the Aleppo, Azaz, Tall-Bashir, Manbic, Tizin, al-Bab, Derkush, and Antioch provinces. Antioch was recorded sometimes to be governed by usual soldiers and many other times by a high-ranking Emir. ${ }^{13}$

The Crusaders driven off from the land brought a centuries-long era of order in the Bilad es-Sham region. The Mamluk rule and order were carried straight to the Ottoman era as well. According to the 16th-century Ottoman records: "Aleppo Sanjak consists of the capital city of Aleppo and 27 hamlets: These are Jabal-i Sem’an, Cebbîl, Bab, Matah, Menbic, Rawandan, 'Amiq, Derbsak, Bakraz (Bakras), Harim, Halka, Jabal-i A’la, Jabal-i Barısha, Jabal-i Bani 'Alim, Sarmin, Jabal-i Samak, Ruc, Zaviyah, Antioch, Suwayda (Suwaydiyya), Kuseyr, Altun-Ozu, Sugur, Jabal-i Akra', Seyzer, Masyaf, and Kefr Tab." ${ }^{14}$ After the reconquest from the Crusaders, Antioch became a bound city to Aleppo in the Bilād al-Shām region on the northern Mamluk border. The Mamluk rule set the stage for the establishment of a long-reigning order.

\footnotetext{
${ }^{12}$ al-Qalqashandī, Subh al-'Ashā, vol. 4, 133-134.

${ }^{13}$ al-Qalqashandī, Subh al-'Ashā, vol. 4, 236-237.

${ }^{14}$ Enver Çakar, "Haleb Sancağında Türkçe Yer Adları”, OTAM, vol. 11, Ankara: Ankara University Press, 2000, 84.
} 


\section{Sultan Baybars' Syrian Campaign and the Conquest of Antioch}

The Ayyubids and Mamluks challenged the Crusader reign over the city during this period. After the conquest of Jerusalem in 1188, Salah al-Dīn began campaigning against Tripoli and Antioch to get a hold on a couple of castles belonging to Tripoli, and managed to establish control over most of the lands governed by Antioch. ${ }^{15}$ Sultan Baybars, who ended the Christian rule over Syria besieged Antioch. The Mamluk army marched on the streets on the 18th of May, 1268. ${ }^{16}$ After an all-out assault, the walls were breached, the city was pillaged since it was taken by force and just like the Crusaders had done earlier, the Christian populace was put to the sword and some were enslaved. The city was burned and devastated. Antioch never reached its former glory. ${ }^{17}$ Sultan Baybars' aforementioned conquest of the city in early

${ }^{15}$ Ramazan Şeșen, "Selâhaddin-i Eyyûbî”, D. F. I. A, vol. 36, İstanbul: Turkish Diyanet Foundation Publications, 339.

16 İbn 'Abd al-Zāhir, al-Rawd al-Zāhir fi Sirat al-Malik al-Zâhir, (ed. Abdulaziz Huveytir), Riyadh: Mu’assasat Fu'ad, 1976, 307; Baybars al-Mansūrī, Mukhtār al-Akhbār Tarikh al-Dawla al-Ayyûbîyya wa Dawla al-Mamālik al-Bahriyya, (ed. Abdulhamid Salih Hamdân), Cairo: ed-Dârül-Misriyyetü'l-Lübnâniyye, 1993, 36, 37; Baybars al-Mansūrī, Kitāb at-Tuhfa al-Mulūkiyya fí Dawla al-Turkiyya, T’arikh Dawla al-al-Mamālik al-Bahriyya, (ed. Abdulhamid Salih Hamdân), Cairo: Dāru'l-ìlm, 1987, 62; Abū al-Fidā, al-Malik al-Muayyad, Tarikh Abī al-Fidā, al-Musamma al-Mukhtasar fi Akhbār al-Bashar, vol. 2, (ed. Mahmud Deyyûb), Lebanon: Beirut American University Press, 1997, 334; al-Maqrizī, Ahmad ibn `Ali, Kitāb al-Sulūk li-Marifet-i Duwal al-Mulūk, Edited by M. Mustafa Ziyadah- Saīd 'Abd al-Fattāh 'Ashūr, vol. 1, (Cairo, 1934), 1958, vol. 1/2, Cairo: al-Hay’ah al-Misriyah, 1957, 566-568; Ibn Tagrībirdī, Abū al-Mahāsin Jamal al-Din Yūsuf, an-Nujūm az-Zāhira fi Mulūk Misr wa al-Qahira, vol. 7, (ed. Muhammed Hüseyin Şemseddin), Lübnan: Dāru'l-Kutubi'l-İlmiyyah, 1992, 128-129; İbn Dokmak, Sārim al-Dīn Ibrahim b. Muhammad, al-Nufhat al-Mıskiyya fi al-Dawla al-Turkiyya, min kitäb al-Jawhar al-Themīn fi Siyar al-Hulefā wa al-Mulūk wa al-Salātin, (ed. 'Umar Abd al-Salām Tadmurī), Beirut: Dāru's-Surûq, 1999, 60; al-Qalqashandī, Subh al-Ashā, vol. 4, 185; Abû'l-Farac (Bar Hebraeus), Abû'l-Farac Tarihi, vol. II, (Trans. into Turkısh Ömer Rıza Doğrul), Ankara: Türk Tarih Kurumu Publications, 1987, 588-589; Ismail ibn 'Umar Ibn Kathir, al-Bidayah wa-al-Nihayah-Büyük İslam Tarihi, (Translated in Turkish by Mehmet Keskin), vol. 12, Istanbul: Çağrı Publications, 1995, 434; Fatma Akkuş Yiğit, "Memlûk - Ermeni Münâsebetleri", Akademik Bakış, vol. 8, p. 16, Ankara: Hale Sivgin, 2015, 178.

${ }^{17}$ Mehmed C. Şehabeddin Tekindağ, "Memlûk Tarihine Toplu Bakış", İ. Ü. Edebiyat Fakültesi Tarih Dergisi, p. 25, 1971, 11. and Halil Sahillioğlu, "Antakya”, D. F. I. A, vol. 3, İstanbul: Turkish Diyanet Foundation Publications, 230. 
April of 1268 with a brief siege meant the abolition of the second established princedom of the Crusades. Continuing his operations against the Crusaders, Sultan Baybars attacked the Kingdom of Tripoli in 1271 and captured many cities and castles. However, the loss of many ships by the storm of the fleet sent to conquer Cyprus in 1270 led to the failure of this expedition. ${ }^{18}$

We can see that in the Sultan Baybars' era, soldiers led by Emir Shams al-Din Sungur al-Rumì were raiding the area to pressure the Antioch. ${ }^{19}$ Sultan Baybars sent messengers to Damascus area for them to prepare for a campaign when he decided to march on the city in 1268. Al-Maqrīzi records that the Crusaders suspected of nothing besides some military activity over Shakif / Beaufort Castle. As it is understood, Sultan Baybars managed to misdirect the Crusaders, his main goal was Antioch and he prepared for the battle meticulously. Sultan had his agenda and continued gradually with tactical perfection. His main goal was still unbeknownst to the Crusaders when he reached Hamāh. Sultan acted swiftly, first he came to Gaza, then to al-Avce and Jaffa. Sultan had warned the commander of Jaffa because he knew that after the Mongols attacked Bire and retreated, they had issued the commander to attack the Mamluks. ${ }^{20}$ So he marched on the castle and captured it the same day. The castle was razed to the ground and the wood and marbles were sent to Cairo. Zāhirī Mosque in Husayniyyah got a wooden maqsurah and a marble altar. Jaffa, which had been under the administration of Gaza during the reigns of Salah al-Din's successors was put under the Remle administrative region during Mamluk rule, which was one of the four coast regions connected to the Damascus. Amirs were given land in these regions and Turkomans were settled there to protect the coastline (al-bilād al-sahiliyyah).

\footnotetext{
${ }^{18}$ Kazım Yaşar Kopraman, “Baybars I”, D. F. I. A, vol. 5, İstanbul: Turkish Diyanet Foundation Publications, 222.

${ }^{19}$ İbn 'Abd al-Zāhir, al-Rawd al-Zāhir, 132.

${ }^{20}$ Reuven Amitai, “The Conquest of Arsuf by Baybars: Political and Military Aspects”, in: Mamluk Studies Review, vol. 9, No. 1, Chicago: Chicago Universty Press, 2005, 68.
} 
After the conquest of Jaffa, the army marched on Shaqif Castle to besiege it lead by Sultan Baybars. ${ }^{21}$ Here, Sultan displayed his perfect military and administrative genius once more. The castle was not only besieged from the outside but also a covert operation was conducted within the walls to capture it, as we will mention later on. After the castle was captured, the Crusader's women and children were sent to Tyre. Shaqif was located on the rocky hills over the Litani River. It was accessible only from a western route because of the cliffs and rocky terrain. After Sultan joined the siege camp, the battle got hardened and 26 great trebuchets begun pounding the walls. It is understood that the messengers sent to the Damascus region resulted in good preparations. Here, Sultan displayed his perfect military and administrative genius once more. When Sultan captured letters sent for reinforcements from Acre, he covertly continued the envoy traffic himself, and defenders were split into two camps due to this trickery. Defenders, knowing that they can't hold the walls without reinforcement gave up. ${ }^{22}$ Ibn al-Kasir clearly states that: "A crusader envoy was captured on road. It was sent to the Shaqif from Acre. They were letters of warning about the Sultans approach to Shaqif and they were telling them to reinforce the defenses and leave no gaps. When Sultan read the letter, he learned how he can get into the city and capture it. He immediately called for a crusader. He ordered a letter in their own language to replace the warning letter sent for the people of Shaqif. He ordered the letter to carry the words of treason directed to both of the governor and the vizier. He wanted to sow discontent amongst the higher ranks." ${ }^{23}$ As the record signifies, the Shaqif campaign was a ruse to cover the main ambitions. The Sultan averted any help by concealing his main goal and conquered yet another stronghold as a byproduct of this diplo-

${ }^{21}$ İbn 'Abd al-Zāhir, al-Rawd al-Zāhir, 292, 295-298; al-Maqrīzī, al-Sulūk, vol. 1/2, 564-565; Abū al-Fidā, Tarikh Abī al-Fidā, vol. 2, 334. and Ebru Altan, "Yafa", D. F. I. A, vol. 43, İstanbul: Turkish Diyanet Foundation Publications, 173.

${ }^{22}$ A. Usta, Haçlı Seferlerinde Kuşatma, 222-223.

${ }^{23}$ Ibn Kathīr, al-Bidayah wa-al-Nihayah, vol. 12, 433-434. 
macy. The Sultan moved to Banyas after the conquest. Then there were many skirmishes over at Tripoli and the nearby region, resulting in many victories and bounty. He then moved to Humus and then to Hamāh.

The Sultan used superior tactics again in Hamāh. He concealed his direction of movement by splitting the army into three divisions. One of those divisions was led by Amir Badr al-Dīn al-Hazindar. Others were respectively led by 'Izz al-Dīn al-Igan/Ogan? and the Sultan himself. While 'Izz al-Dīn led his soldiers towards Derbsak (today located between Hatay/ Kırıkhan and Hassa), Bedreddin moved to Suwaydiyya ${ }^{24}$ (today Samandag) and the Sultan moved to Afamiya, Northeast of Hamāh. So the Sultan entered the Asi River basin. After this split, all armies started marching towards Antioch. ${ }^{25}$ As reflected by the records, this split on Hamāh helped Sultan to cover his main ambitions to prevent any help to Antioch; he sent a powerful force through Suwaydiyya to the port and coastline to block any help from Tripoli and the sea and he himself approached from the South, he sent another army to approach from the North through Derbsak which also blocked any help from the Armenians and finally, he marched on Afamiya from South to fully encircle the city. Being a shrewd tactician, Sultan must have made this split plan according to the cities current situation and over the probability of any help from Tripoli. Sultan made many conquests in Syria, concealing his ultimate goal when he was marching on it. Sultan Baybars conquered Jaffa and Shaqif Castles on the road and destroyed them, then he split his army into three divisions as mentioned above to hide his next move and to encircle the city. Being one of the most prominent strongholds of the Crusaders, the Antioch's conquest meant that yet another great political power of the Crusaders was no more and Turk-Islamic harmony and rule over the region could now flourish and expand.

The city was governed by the Bohemond IV when Baybars appeared outside the city walls. The Sultan's opinion of the city changed within the

${ }^{24}$ al-Qalqashandī writes that as-Suwadiyya is the port of Antioch. al-Qalqashandī, Subh al-'Ashā, vol. $4,134$.

${ }^{25}$ İbn 'Abd al-Zāhir, al-Rawd al-Zāhir, 299, 308. and al-Maqrīzī, al-Sulūk, vol. 1/2, 566-567. 
first days of Ramadan and his armies approached the city from multiple directions and set camps. Vanguard led by Emir Semseddin Aksungur came into contact with the Antioch soldiers and a skirmish ensued. Antioch was attacked from all sides. Sultan Baybars, as customary, sent an envoy before the attack to the city informing them that he had arrived and they should give the city. By doing so he also revealed his intention and they were terrified. The army outside encircled the city from the mountainside and parts outside the walls were conquered, inhabitants then fled into the fort. Emirs who joined the siege made sure that no one could leave the city. Approximately 8 thousand people apart from the children and women were inside the city. Ultimately the city dwellers yielded and the Sultan conquered the city. ${ }^{26}$ Ibn Ibn Tagrïbirdī contradicts al-Maqrīzīs record, stating that the city was captured ${ }^{27}$ upon the request for mercy. Abū al-Fidā also states that the city was conquered by the sword. The Sultan's permit of sacking and the bounty being distributed by chalices indicates that the city was conquered forcefully and the army acted accordingly. The Sultan left the castle under Amir Badr al-Dīn Bilik al-Khazindar and Amir Badr al-Dīn Baysarī al-Shamsī. Aleppo Muslims who were captives were set free. The Sultan personally oversaw the distribution of loot for two days straight. As he did with other Crusader castles, the Sultan made his man burn the city fort. These forts being set ablaze was a policy in effect since Salahaddin to make sure that the Crusaders could never use them again. It is recorded that some nearby castles were also pleaded for mercy and surrendered. The control over the area was strengthened. Emir Bilik al-Ashrafi saw the conquest of these places. ${ }^{28}$ The people of al-Kusayr sent a letter to surrender. Amir Shams al-Din Aksungur al-Farikanì was sent to accept the plea. Derkus inside Aleppo province was also conquered like that. Bagras, people of which had fled, was also captured. ${ }^{29}$ We can see that diplomacy

${ }^{26}$ İbn 'Abd al-Zāhir, al-Rawd al-Zāhir, 308-310. and al-Maqrīzì, al-Sulūk, vol. 1/2, 567.

${ }^{27}$ Ibn Tagrībirdī, an-Nujūm az-Zāhira, vol. 7, 128.

${ }^{28}$ İbn 'Abd al-Zāhir, al-Rawd al-Zāhir, 313; al-Maqrīzī, al-Sulūk, vol. 1/2, 568. and Abū al-Fidā, Mukhtasar, vol. 2, 334.

${ }^{29}$ Ibn Tagrībirdī, an-Nujūm az-Zāhira, vol. 7, 129. and Abū al-Fidā, Mukhtasar, vol. 2, 334. 
with Armenians was also conducted after the conquest. King Leon, son of Hethum of Armenia was taken captive in the 1266 campaign and then he was traded for a captive Mamluk emir and six castles. ${ }^{30}$ Egypt, Damascus, and some Frankish countries were informed about Sultan Baybars' success. The Sultan moved to Seyzer and then to Humus, continuing the campaign over the region. He arrived in Damascus for the Eid al-Fitr and returned to Cairo on the eleventh day of Zilhicce month. ${ }^{31}$ Sultan's 4-month campaign resulted in many castles besides Antioch captured and his power on the northern border regions expanded while the Crusader power diminished.

The conquests of Baybars expanded his power in the North and the Crusaders needed to act. As mentioned: "Sultan's conquest of Antioch and the end of 170 years of Crusader rule over the area was a huge blow to the Crusaders. So, the English heir to the throne Prince Edward, son of King Henry the Third took the Cross and arrived in Cyprus in the spring of 1271 and then sailed for Acre. King Hugue the Second of Cyprus died in 1267 and his regent Hugue d'Antioche-Lusignan became his successor, named Hugue the Third (1267- 1284) who became King in Acre. When Sultan Baybars learned that Hugue III was leaving Cyprus for Acre, he sent a fleet of 17 ships to attack Cyprus. The fleet suddenly appeared near Limassol but wasn't successful and most of the Muslims were taken as captives by the Cypriots (1271)". ${ }^{32}$ Bohemond VI and his son Bohemond VII lived the rest of their lives in Tripoli after they lost their city, Antioch. ${ }^{33}$ The Crusaders wanted to react to this loss via Cyprus but they were repelled. Cyprus became the main stronghold for the Crusaders as most of their power in northern Syria was no more. Later, Cyprus was conquered in Barsbay's reign and the Crusader entity was eliminated.

\footnotetext{
${ }^{30}$ Peter M. Holt, Haçlılar Çă̆ı, (Translated into Turkish by Özden Arıkan), Istanbul: Tarih Vakfi Yurt Publications, 1999, 160.

${ }^{31}$ Ibn Tagrībirdī, an-Nujūm az-Zāhira, vol. 7, 129-130.

${ }^{32}$ Ebru Altan, "Kıbrıs Haçlı Krallığı (1191-1489)”, Türkler, vol. 6, Ankara: Yeni Turkiye Press, 2002, 695-696. and Saīd Abd al-Fattāh 'Ashūr, Kubrus ve Hurubu's-Salibiyya, Cairo: Dāru’n-Nahda, 1957, 47-48.

${ }^{33}$ P. M. Holt, Haçlılar Çağı, 32.
} 
The Crusader effort to react to the loss of Antioch was to no avail as Sultan expanded his control over the region and prepared for the final push to expel the last remnants of the Crusaders. Sultan Baybars conquered castles near Antioch peacefully or with force to hold key crossing points in the Northern Syria and he restricted the Crusaders to a small area of influence. As Prof. Dr. Kazım Yasar Kopraman indicates: “The fall of Antioch into Muslim hands in 1268 was a huge event. Antioch was the second founded (1207) Crusader state after Odessa and its fall was another evidence that the Crusader structure that was established in the 11th century has been collapsing." ${ }^{4}$ The following 20 -30 years saw the Crusaders losing their last castles and they were expelled finally.

Sultan Baybars' Antioch campaign was a four-month operation, starting with an envoy sent to Damascus and planned meticulously to deal an ultimate blow to the Crusaders, and carried with perfect tactics to find success. This success was inevitable with strategic planning, a well-equipped army, sheer political will, and the Sultan being a shrewd tactician and a clever politician. He concealed his true intentions and marched on Shaqif, then he split his army to cover the entire area and finally besieged the city and conquered it, showing that he led his men as a great statesman and a capable commander. After the campaign, the Turkomans who settled in the region changed te political and cultural status in the area. The shaping of the region during the Mamluk reign meant that a new order emerged, and lasted for a long period of time. Sultan Baybars's campaign of 1268 was recorded in history as a campaign with long term effects.

The Mamluk relations with the Crusaders, Mongols, Armenians, and Cyprus Crusaders were interrelating and complex, as can be seen in this work studying the Conquest of Antioch. It can be seen more clearly when researching Armenian and Cyprus Crusader Kingdoms' destruction by the Mamluks. Over time, the Mamluks fought against these powers to eliminate the threats and they made a huge impact on the region's political and cultural unification.

\footnotetext{
${ }^{34}$ Kazım Yaşar Kopraman, “Memlûkler”, D. G. B. İ. T, vol. 6, Istanbul: Çağ Publications, 1990, 465.
} 
This fight for survival started with the establishment of the Mamluk state which saw its ultimate end in Syria. Sultan Baybars attacked Princedom of Tripoli in 1271. He conquered the castles of Safita, Hisnu'l- Akrad, and Hisn-i Akkar. He captured Hisnu'l- Karin, in the northeast of Acre. This castle was controlled by the Teutonic Order. Because of the Cypriot King working towards a union of Syrian Crusaders and Cypriots attacking Muslim ships in the Eastern Mediterranean, the Sultan sent a fleet to capture the island in 1270 but the majority of the fleet was destroyed by a storm and the campaign failed. ${ }^{35}$ When Sultan Baybars (1260- 1277) was on the campaign in 1271, the envoys from Tripoli and Cyprus arrived with peace offers. When the envoy of Cypriot King stated that the king demands Baalbek and Nablus from the Sultan, he said: "Is your king sane? I am storming your keeps one by one and he demands territory? How?"36. Baybars was a great statesman and a great warlord, so his struggle against the crusaders was also great and even though his life ended, the struggle was continued by successors within the frame that he had built.

\footnotetext{
${ }^{35}$ Kazım Yaşar Kopraman, “Memlûkler”, Türkler, vol. 6, Ankara: Yeni Türkiye Yayınları, 2002, 87, 101-102, 103; al-Yunūnī, Abū al-Feth Kutb al-Din Musā ibn Muhammad ibn Abdallah, Zayl Mir'at al-Zamān, (Edited Hamza Abbâs), vol. 3, Abu Dhabi: el-Mecmaü’s-Sekafî, 2007, 255; Wilhelm Barthold, İslâm Medeniyeti Tarihi, (İlâveler-M. Fuat Köprülü), Ankara: Türk Tarih Kurumu Publications, 1963, 335; al-Maqrizī, Ahmad ibn `Ali, Kitāb al-Sulūk li-Marifet-i Duwal al-Mulūk, Edited by M. Mustafa Ziyadah- Said Abdulfattah Ashūr, vol. 1, Cairo: al-Hay’ah al-Misriyah, 1934, 362, 1170; al-'Aynī, Badr al-Din Mahmud ibn Ahmad, 'Ikd al-Jumān fi Tarihi Ahl al-Zaman, Edited by Muhammad Muhammad Emin, vol. 4, Cairo, 1989, 380; İbn Hajar, Inbā al-Gumr bi Abnā al-'Omr, (Edited by Abdulvehhab al-Buharî), vol. 5, Beirut: Dar al-Risalah al-Alamiyyah, 1986, 133; Ibn Tagrībirdī, Abū al-Mahāsin Jamal al-Din Yūsuf, an-Nujūm az-Zāhire fi Mulūk Misr wa al-Kahira, Edited by Muhammad Husayn Shamsaddin, vol. 7, Cairo: Dāru'l-Kutubu'l-İlmiyyah, 1963, vol. 8, p. 5, vol. 14, 122; al-Șayrafī, Hatib al-Jevherī Ali ibn Davud, Nuzhat al-Nufūs wa al-Abdān fi Tawārih al-Zaman, Edited by Hasan Habeshi, vol. 3, Cairo: al-Heye' al-Misriyyah al-Ammah li'l-Kitab, 1974, 272; Abū'l-Fidā, al-Mukhtasar, events of year 6691. (Ebu'l-Fidâ, 'İmâd al-Dīn İsmail b. Ali, al-Mukhtasar fī Akhbār al-Bashar), Cairo: Dāru’l-Tibā‘at al-Shāhānīyah, 1286; Ali Aktan, "Memlûk-Haçlı Münasebetleri”, Belleten, vol. 237, Ankara: Türk Tarih Kurumu, 1999, 419, 421-422, 424-426; Mufaddal b. Abi'l-Fadāil, an-Nahc al-Sadīd wa al-Durr al-Farīd fimā Bad Tarikh Ibn 'Amid, (ed. by E. Blochet), vol. 2, Belgium: Patrologia Orientalis, 1983, 198-199.

${ }^{36}$ Aybak al-Dawādārī, Abu Bakr ibn Abdallah ibn 'Izz al-Din, Kanz ad-Durar wa Jāmi' al-Gurar/ al-Durrat az-Zakiyya fi Ahbār al-Dawla at-Turkiyya, Edited by Ulrich Haarmann, vol. 8, Cairo: Sāmi el-Hanci, 1971, 161-162.
} 
After Baybars, the Ottomans, the Western Mediterranean Beyliks, and the Mamluks endured new waves of the Crusaders as the bulwarks of the Islamic World in the 14th centruy. This era of the Crusades has not been researched completely yet. Syria, being the primary topic for this research and other attacks on the Eastern Mediterranean should be seen as a whole historical process. The mentioned campaigns, which were led by the French King Philip VI have many recored plans and drafts. One of the most exciting is the one which has been stated by Marino Sanuto Torsello." "When Acre, the last Crusader bastion in the East Mediterranean, has fallen as expected in 1291 to the Mamluks, it created vast reactions in the Christian West. After the fall of Acre to Philip VI's plans for a crusade, many projects, plans and proposals were drafted by the royal family members, traders, diplomats, clergy, and military men as well to reclaim the Holy Land. At first, the consensus weighed towards a plan to invade Egypt, the land of "heretic Muslims" and Istanbul, the capital of "deviant Christians" and then reclaim the Holy Land. But within the first quarter of the 14th century, the Turkish West Anatolian naval Beyliks had grown as the primary threat to the Latin interest in Aegea, so the focus shifted to establish naval Crusades against them." ${ }^{38}$ Therefore, all these affairs should be seen as connected. For the goal of this study, we will analyze the attacks in the East Mediterranean and the Mamluk reaction. We should also mention the Ottoman victory at Nicopolis in 1396 for the sake of uniformity on the subject.

In Sultan Zayn al-Dīn II Shaban al-Asraf's era (1363-1376) the island of Cyprus was held by the Lusignan dynasty and it had been an important base since the 3rd Crusade (1192). The rulers of the island used it to stage attacks on Muslim states and hamper the Mamluk sea trade. "At the end of the 13th century, the land was completely left to the Muslims, so the consequent struggle that emerged after can be categorized in the litera-

\footnotetext{
${ }^{37}$ See: Serdar Çavuşdere, Marino Sanudo Torsello’nun XIV. Yüzyılın İlk Yarısında Ege’de Egemenlik Mücadelesi, 1291, 1353, Latinler, Denizci Türkmenler ve Haçlllar, Ankara University, History Department- Medieval History, 2014. (Unpublished Phd Thesis)

${ }^{38}$ Serdar Çavuşdere, “Türklere Karşı Haçlı Donanma İttifakı Teşebbüsü ve İzmir Haçlı Seferi: 1341 1351", in: Journal of History School, March 2015, İzmir: Tarih Okulu Press, 1-3.
} 
ture as the Crusade plans and projects, and these organized efforts were realized not in the Eastern Mediterranean, but the Aegea in the form of the Crusader fleets against Turks of the region. Most of these projects comprised of well equipped grand fleets to be put together to attack the Muslims and plans regarding these prepared to be offered to the Popes and Kings, for example, the French King. But the main objective of these plans and the Allied Fleet, to be established, was not the Holy Land anymore, the focus was shifted to the Turks who settled in the Anatolian peninsula for nearly 200 years and reshaped the region socio-politically, and then settled in the western coast of Anatolia to change the rules of the game." ${ }^{39}$ They attacked not only the Muslim trade ships but also the key port cities. Added to the status at hand, Cyprus gained a heroic Crusader spirit due to its location and the son of the so-called Cyprus King Hugh IV, ruler Pierre de Lusignan (1359-1369) was carrying this fervor to the extreme, so Egypt saw the greatest and most destructive attack of the Crusades in 1365. There is a rumor that this attack was carried because the Mamluks had not let the King sit on a pillar in the city of Tyre, which was a symbol of kingship in Cyprus. ${ }^{40}$ Pierre had conquered the city of Antalya in 1361. The King gathered the Knights of Rodos and Genoese under his banner and sailed with 20 ships from Famagusta and after a 12-day siege, he captured this place on August 12, 1361, killed the Turks and plundered the city. Subsequently, a Latin Church affiliated to Cyprus has also been established here. Meanwhile, the naval commander Jean de Sur captured the hamlet of Myra, defeated the garrison loyal to Teke Beg and pillaged the St Nicholas Church which was standing there since the Romans and the Byzantines and never saw any mistreatment by the Turks, and shipped the painting of St Nicholas to Cyprus to be displayed in the church of the same name. Hamlet was governed by the Cypriot Crusaders until Teke Beg brought it back into the fold in $1373 .{ }^{41}$ Pierre

\footnotetext{
${ }^{39}$ Ibidem, 2-3.

${ }^{40}$ P. M. Holt, Haçlılar Çă̆ $1,114$.

${ }^{41}$ Osman Turan, "Ortaçağlarda Türkiye-Kıbrıs Münasebetleri”, Selçuklular ve İslâmiyet, Istanbul:
} 
de Sur continued his aggressive attacks, he attacked Tripoli on the Syrian coastline in 1367 but failed to capture it. So the Crusaders attacked again with 130 ships of "shini, qarqure, gurab, taride, and shahtur types". The King of Rodos and the Hospitaller Knights also joined the campaign.

The Viceroy of the city was not present. The Mamluks of the city defended it fiercely but to no avail and they fell back, leaving approximately 1000 Crusaders and 40 martyrs ${ }^{42}$ on the field of battle. The attacks continued: Alexandria again in 1368, Tripoli in 1401 and 1403, and then to Beirut and Sayda. ${ }^{43}$ Ayas was also attacked and captured but the Cypriot Crusaders were driven off shortly after. ${ }^{44}$ The Mamluk historians liked to record coincident and likelinesses, so historian Ashraf Shaban writes how one of his sons was now a prisoner in Alexandria in Ashraf Baybars' era but his grandfather had pillaged it back then, and he begs Allah for mercy. ${ }^{45}$ Sultan Barsbay's success made the Mamluks a force to be reckoned with again. ${ }^{46}$ As can be seen, the Balkans, Aegean coasts, and all of the Eastern

Boğaziçi Publications, 1993, 142, 143. and Işın Demirkent, Haçlı Seferleri, Istanbul: Dunya Press, 1997, 263-264.

${ }^{42}$ al-Maqrīzī, al-Sulūk, vol. 3, 149; Tarikh Malik Ashraf Qayıtbay, (anonymus), (ed. 'Umar Abd alSalām Tadmurī), Beirut: al-Maktabatu’l-Asriyyah, 2003, 77. and Kazım Yaşar Kopraman, Makaleler, (Edited by E. Semih Yalçın-Altan Çetin), Ankara: Berikan Publications, 2005, 623.

${ }^{43}$ Saìd 'Abd al-Fattāh 'Ashūr, al-Ayyubiyyūn wa al-Mamālīk fî̀ Misr wa al-Sham, Cairo: Dāru'l-Nahda al-Arabiyyah, 1996, 276.

${ }^{44}$ A. Aktan, "Memluk-Haçlı Münasebetleri”, 448.

${ }^{45}$ al-'Aynī, 'Iqd al-Jumān fi Tarikh Ahl al-Zaman, Nuruosmaniye Kütüphanesi, Veliyüddin Kitaplığı, No: 2396, 584-585; Sālih b. Yahya, Tärīkh Bayrūt, (ed. Francis Hours-Kamal Sulayman Salib), Beirut: Dârü'l-Meşrik, 1969, 242-251. (Cyprus Campaigns of Baybars era are widely discussed here.); Leonitos Makhairas, Recital Concerning the Sweet Land of Cyprus, (Edited and Translated by R.M. Dawkins), I, Oxford: Clarendon Press , 1932, 652, 672, 696, 701; Ibn Tagrībirdī, an-Nujūm az-Zāhira, vol. 14, 292-304; Tarikh Qayıtbay, 131-132, 135, 136-137, 138-139, 140, 141; Zayn al-Dīn 'Abd al-Bāsịt Khalīl ibn Shāhīn al-Zāhirī, Nayl al-Amal fì Dhayl al-Duwal, (ed. 'Umar Tadmurī), vol. 4, Beirut: al-Maktaba al-Asriyyah, 2002, 196-197, 199, 200, 201-202; Mohammed Mustafa Ziyadah, "The Mamluk Conquest of Cyprus in the Fifteenth Century", Bulletin of the Faculty of Arts, vol. I, Part I, Cairo: Universty of Egypt, 1933-1934, 90-113; K. Y. Kopraman, Makaleler, 136-137, 649-651; 'Ashûr, al-Ayyubiyyūn wa al-Mamālīk, 277-279; İ. Yiğit, "Memlûkler", 112; O. Turan, "Ortaçağlarda Türkiye-Kıbrıs Münasebetleri”, 144.

${ }^{46}$ Stephen R. Humphreys, "Egypt in the World System of Later Middle Ages", in: The Cambridge History of Egypt, (ed. Carl F. Petry), Cambridge: Cambridge University Press, 2008, 458. 
Mediterranean were under attack in the 14th century. These attacks were repelled and the Eastern Mediterranean was cleared from the Crusaders by the Mamluks over time.

\section{End of the Armenian Kingdom in Cilicia}

Constantin the V, who was the son of a Cypriot warlord upsurged the Armenian throne and offered it to Peter, the King of Cyprus who attacked Alexandria in 1365 and caused a great devastation there, but he was killed in 1369 so Constantin named himself the Cilician Armenian King. He was killed in 1373 so the last king Leo VI was coronated. The Mamluks ended the kingdom during Sultan al-Malik al-Ashraf Zayn al-Dīn II Shaban bin Husayn's era (1363-1376). A messenger pigeon sent by the viceroy of Damascus, Emir Beydemir to Cairo gave the news of the conquest of Sis, the capital of the Kingdom of Cilician Armenians. The conquest was carried by the soldiers led by Isiktemur, viceroy of Aleppo. The city of Sis, which was the throne city of the "tekfur" as mentioned by the Mamluks was besieged for 2 months. The city surrendered due to food supplies running out. The king, his men, and soldiers were arrested. The place was not a dar-1 harb (land of battle) but dar-1 Islam (land of Islam) now. So the Crusader-Armenian existence was destroyed. Yakub Shah was appointed as the viceroy. Tarsus, Adana, Masisa, and nearby hamlets were consequently conquered and these conquests were named "al-Futuhat al-Cahaniyya" (conquests of Ceyhun) after Halil bin Sahin's record. ${ }^{47}$ The conquest had many results. For example, the Mamluks had been purchasing the wood they needed from the Genoese. Renowned traveler Ibn Battuta also traveled between Lazkiye (Syria) and Alaiye

\footnotetext{
${ }^{47}$ 'Abd al-Bāsịt Khalīl ibn Shāhīn al-Zāhirī, Nayl al-Amal, vol. 2, Beirut: al-Maktaba al-Asriyyah, 2002, 89; al-Maqrīzī, al-Sulūk, vol. 3, 237-238; Jacob G. Ghazarian, The Armenian Kingdom in Cilicia during the Crusades: The Integration of Cilician Armenians with the Latins (1080-1393), Oxford, Routledge, 2000, 54-55. and Mehmet Ersan, Selçuklular Zamanında Anadolu'da Ermeniler, Ankara: Türk Tarih Kurumu Publications, 2000, 230.
} 
by Genoese ships. ${ }^{48}$ As the Cilician Armenian Kingdom ended in the mid-14th century, the Muslim traders took place. ${ }^{49}$

\section{Conquest of Cyprus, Control of the Mediterranean}

After the introduction given in the general framework, we can move on to the details of the events regarding Cyprus. Al-Ayni who lived in the period of Barsbay and was very close to him, mentions that Cypriots intercepted the ships coming from Biläd al-Rûm (Anatolia) to Damietta and Alexandria, made banditry at sea, and rebelled against Sultan Barsbay as the reasons for the conquest of Cyprus. He also notes that the Sultan had a great preparation against these attacks and embarked on a great expense. ${ }^{50}$

In the records of 1422, there are reports that Franks (Crusaders) attacked the Mamluk beaches (Egypt-Syria). ${ }^{51}$ In the following year, against the Frankish attacks, the Sultan started to take measures by sending orders and soldiers to Damietta, Rashid, and Alexandria. ${ }^{52}$ In 1423, during the reign of Sultan Barsbay (1422-1438), an incident took place that would evoke the Mamluk State bearing the traumatic traces of the 1365 attack. A large ship found in the port of Damietta, belonging to a Muslim merchant named Ahmad bin al-Hamim, was grabbed by the pirates of the king of Cyprus and taken there, ${ }^{53}$ but the Sultan retaliated by seizing the property of Frankish merchants in Syria, Dimyat and Alexandria and did not release the merchants until compensation for the damage was paid. ${ }^{54}$

\footnotetext{
${ }^{48}$ Wilhelm Heyd, Yakın-Doğu Ticaret Tarihi, (Translated by Enver Ziya Karal), Ankara: Türk Tarih Kurumu Publications, 1977, 610.

${ }^{49}$ Eliyahu Asthor, Levant Trade in the Later Middle Ages, Princeton: Princeton University Press, 1983, 28; Peter W. Edbury, The Kingdom of Cyprus and the Crusaders (1191-1374), London: Cambridge University Press, 1991, 134.

${ }^{50}$ al-'Aynī, 'Iqd al-Jumān fi T'arikh Ahl al-Zaman, Nuruosmaniye Kütüphanesi, Veliyüddin Kitaplığı/ Nuruosmaniye Library, Veliyüddin Library, No. 2396, 572.

51 'Abd al-Bāsịt Khalīl ibn Shāhīn al-Zāhirī, Nayl al-Amal, vol. 4, 115.

${ }^{52}$ Ibidem, 138.

${ }^{53}$ S. Yahya, Tārīkh Bayrūt, 242.

${ }^{54}$ P. M. Holt, Haçlılar Çağı,186.
} 
In addition to this, the King of Cyprus Janus (1398-1432) captured the ship carrying gifts sent to Murad and that was the last straw. A piece of information that supports all these reasons was provided by Ibn Hajar. According to the information here, in 1424 Rebiu'l-Evvel month, Ash-Sheikh Mohammed b. Kudeydâr sent his son to the king of Cyprus with the promise that he would help him visit the Kamame church in return for the prisoners held captive. However, the Sheikh's son was arrested and Sheikh Mohammed was very upset about it. ${ }^{55}$ Again in 1424, some orders had been given to these areas after receiving the news that the Franks (Crusaders) were going to attack the beaches. In the same year, a group of Franks attacked the Sur beaches. Again that year, the clashes took place between Jabala and Tripoli, between Muslims and Crusaders. ${ }^{56}$ All the mentioned processes and events resulted in protracted crusades and unsuccessful attempts to achieve peace. Precisely for that reason, the sultan decided on military action and he occupied the island during three military campaigns in 1424, 1425, and 1426.

As an example of the way Mamluk historians like to record the coincidences and similarities, the historian Ashraf Shaban mentions that one of the sons of the Crusader King entered Alexandria as a prisoner during the time of Ashraf Barsbay, ${ }^{57}$ which was plundered by his grandfather in the time of Shaban. This success of Sultan Barsbay made the Mamluks one of the respected and serious military powers of the world again. ${ }^{58}$

\footnotetext{
55 'Abd al-Bāsịt Khalīl ibn Shāhīn al-Zāhirī, Nayl al-Amal, vol. 4, 169; Ibn Hajar al-Askalānī, Inbâ al-Ghumr bi-Abnā al-'Omr, (Edited by Abdulvehhab al-Buharî), vol. 5, Beirut: Darul'Baz, 1986. There is two editors in differant volumes; in vol. 8: Edited by Muhammed Abdulmuid Han, Beirut: Daru'l-Baz, 1986, 64.

56 "Abd al-Bāsịt Khalìl ibn Shāhīn al-Zāhirī, Nayl al-Amal, vol. 4, 171, 172.

${ }^{57}$ S. Yahya, Tārīkh Bayrūt, 242-251.(Cyprus Campaigns of Baybars era are widely discussed here.); Makhairas, Recital Concerning, I, 652, 672, 696, 701; Ibn Tagrībirdī, an-Nujūm az-Zāhira, vol. 14, 292-304; Tarikh Qayıtbay, 131-132, 135, 136-137, 138-139, 140, 141; 'Abd al-Bāsịt Khalīl ibn Shāhīn al-Zāhirī, Nayl al-Amal, vol. 4, 196-197, 199, 200, 201-202; Mohammad Mustafa Ziyadah, "The Mamluk Conquest of Cyprus in the Fifteenth Century, Bulletin of the Faculty of Arts", Universty of Egypt, vol. I, Part I, Cairo: Cairo Univesity, 90-113; K. Y. Kopraman, Makaleler, 136-137, 649-651; 'Ashūr, al-Ayyubiyyūn wa al-Memālīk, 277-279; İ. Yiğit, «Memlûkler”, 112. and O. Turan, "Ortaçağlarda Türkiye-Kıbrıs Münasebetleri", 144.

${ }^{58}$ R. S. Humphreys, "Egypt in the World system of Later Middle Ages”, 458.
} 
As a result, the Crusaders' presence in the Eastern Mediterranean coasts, where they could really dominate after the 1 st Crusade, was thus eliminated. The struggle that took place in the period after Sultan Baybars and later resulted in the fact that the defense against the Crusader attacks was first poured into the Mediterranean and then they were completely removed from there. The great Crusader attack in the 14th century spread over a century from different fronts and took place over the Balkans, the Aegean, and the Eastern Mediterranean. After the main body of the Crusaders was removed from Syria, the Armenian and Cypriot structures, acting as their deputies, were also destroyed in the following periods. Thus, the occupation before the unification and development of the region was abolished and this region would no longer be a headquarters area for the Crusades, which would continue in different ways during the Ottoman period. The Mediterranean became a place where the Crusaders cannot sail again with the success of the Mamluks. In the Ottoman period, this situation will get stronger and stability will continue until the events of the 19th century.

\section{SOURCES AND LITERATURE}

\section{Archival sources}

AL-'AYNİ, 'Iqd al-Jumān fi Tarikh Ahl al-Zaman, Nuruosmaniye Kütüphanesi, Veliyüddin Kitaplığı, No: 2396.

\section{Published sources}

Abū al-Fidā, al-Malik al-Muayyad, Tarikh Abī al-Fidā, al-Musamma al-Mukhtasar fì Akhbār al-Bashar, vol. 2, (ed. Mahmud Deyyûb), Lebanon: Beirut American University Press, 1997.

Abû'l-Farac (Bar Hebraeus), Abû'l-Farac Tarihi, vol. II, (Trans. in Turkish. Ömer Rıza Doğrul), Ankara: Türk Tarih Kurumu Publications, 1987. 
Aal-'Aynī, Badr al-Din Mahmud ibn Ahmad, 'Iqd al-Jumān fi Tarikh Ahl al-Zaman, Edited by Muhammad Muhammad Amin, vol. 2, Cairo: al-Heye al-Amme al-Misriyyah li'l-Kitab, 1989.

Al-Maqrizī, Ahmad ibn `Ali, Kitāb al-Sulūk li-Marifet-i Duwal al-Mulūk, (Edited by M. Mustafa Ziyadah- Saīd 'Abd al-Fattāh 'Ashūr), vol. 1, Cairo: al-Hay’ah al-Misriyah, 1934-1958.

Al-Qalqashandī, Shihab al-Din Ahmad ibn 'Ali, Subh al-Ashā fi Sinäat al-Inshā, Edited by Muhammad Husayn Shemseddin, vol. 4, Beirut: Dāru'l-Kutubu'l-İlmiyyah, 1987.

Al-șayrafī, Hatib al-Jevherī Ali ibn Davud, Nuzhat al-Nufūs wa al-Abdān fi Tawārih al-Zaman, (Edited by Hasan Habeshi), vol. 3, Cairo: al-Heye' al-Misriyyah al-Ammah li'l-Kitab, 1974.

Al-Yunūnī, Abū al-Feth Kutb al-Din Musā ibn Muhammad ibn Abdallah, Zayl Mir'at al-Zamān, Edited Hamza Abbâs), vol. 3, Abu Dhabi: el-Mecmaü’s-Sekafî, 2007.

Al-Zāhirī, Zayn al-Dīn 'Abd al-Bāsịt Khalīl ibn Shāhīn, Nayl al-Amal fì Dhayl al-Duwal, (ed. 'Umar Tadmurī), vol. 4, Beirut: al-Makataba al-Asriyyah, 2002

Aybak al-Dawādārī, Abu Bakr ibn Abdallah ibn 'Izz al-Din, Kanz ad-Durar wa Jāmi' al-Gurar/ al-Durrat az-Zakiyya fi Ahbār al-Dawla at-Turkiyya, Edited by Ulrich Haarmann, vol. 8, Cairo, 1971.

Baybars al-Mansūrī, Kitāb at-Tuhfa al-Mulūkiyya fī Dawla al-Turkiyya, T'arikh Dawla al- al-Mamālik al-Bahriyya, (ed. Abdulhamid Salih Hamdân), Cairo: Dâru'l-i̇lm, 1987.

Baybars al-Mansūrī, Mukhtār al-Akhbār Tarikh al-Dawla al-Ayyûbîyya wa Dawla al-Mamālik al-Bahriyya, (ed. Abdulhamid Salih Hamdân), Cairo: ed-Dârü'l-Misriyyetü'l-Lübnâniyye, 1993.

Fulcher of Chartes. The First Crusade, The Chronicle of Fulcher of Chartres and Other Sources Materials, (ed. by Edward Peters), Philadelphia: Penguin Classics, 1998. 
İbn 'Abd al-Zāhir, Muhyyī al-Dīn, al-Rawd al-Zāhir fí Sirat al-Malik al-Zâhir, (ed. Abdulaziz Huveytir), Riyadh: Mu’assasat Fu'ad, 1976.

İbn Dokmak, Sārim al-Dīn Ibrahim b. Muhammad, al-Nufhat al-Miskiyya fi al-Dawla al-Turkiyya, min kitāb al-Jawhar al-Themīn fì Siyar al-Hulefā wa al-Mulūk wa al-Salātin, (ed. 'Umar Abd al-Salām Tadmurī), Beirut, 1999. İbn Hajdar, Inbā al-Gumr bi Abnā al-'Omr, (Edited by Abdulvehhab al-Buharî), vol. 5, Beirut: Dârul-Baz, 1986.

Ibn Kathir, Ismail ibn 'Umar, al-Bidayah wa-al-Nihayah-Büyük İslam Tarihi, (Translated in Turkish by. Mehmet Keskin), vol. 12, Istanbul: Çağrı Publications, 1995.

Ibn Tagrībirdī, Abū al-Mahāsin Jamal al-Din Yūsuf, an-Nujūm az-Zāhira fi Mulūk Misr wa al-Qahira, vol. 7, (ed. Muhammed Hüseyin Şemseddin), Lübnan: Daru'l-Kutubu'l-İlmiyyah, 1992.

Makdīsī, Muhibeddin Ebu Hamīd, Türk Memlüklerin Faziletleri, (Translated by Ramazan Şeşen), Istanbul: Yeditepe Publications, 2019.

Makhairas, Leonitos, Recital Concerning the Sweet Land of Cyprus I, (ed. Richard M. Dawkins), Oxford: Clarendon Press, 1932.

Mufaddal bin Abi'l-Fadāil, an-Nahc al-Sadìd wa al-Durr al-Farìd fimā Ba'd Tarikh Ibn 'Amid, (ed. by E. Blochet), vol. 2, Belgium: Patrologia Orientalis, 1983.

Sālih b. Yahya, Tārīkh Bayrūt, (ed. by Francis Hours-Kemal Süleyman Salibî), Beirut: Dâru'l-Meşrik, 1969.

TARIKKH MALIKK ASHRAF QAYITBAY, (Anonimius), (ed. 'Umar Abd al-Salām Tadmurī), Beirut: al-Maktaba al-Asriyyah, 2003.

\section{Literature}

\section{Books}

'Ashūr, Saīd 'Abd al-Fattāh, al-Ayyubiyyūn wa al-Mamālīk fì Misr wa al-Sham, Cairo: Dâru'n-Nahdati'l-Arabiyyah, 1996. 
'Ashūr, Saīd 'Abd al-Fattāh, Kubrus ve Hurubu's-Ṣalibiyya, Cairo: Dāru'nNahda, 1957.

Akdağ, Mustafa, Türkiye’nin İktisadi ve İçtimaî Tarihi, vol. 1, Istanbul: Cem Publications, 1995.

Aal-Yûzbekî, Tawfiq, Tarihu Ticara Misr al-Bahrîyya fi Asri'l Mamâlîk, Mosul: Matbaatü'l-İrşad, 1975.

Asthor, Eliyah, Levant Trade in the Later Middle Ages, Princeton: Princeton University Press, 1983.

Barthold, Wilhelm, İslâm Medeniyeti Tarihi, (İlâveler-M. Fuat Köprülü), Ankara: Türk Tarih Kurumu Press, 1963.

Demirkent, Işın, Haçlı Seferleri, Istanbul: Dunya Publications, 1997.

Edbury, Peter W, The Kingdom of Cyprus and the Crusaders (1191-1374), London: Cambridge University Press, 1991.

Ghazarian, Jacob G, The Armenian Kingdom in Cilicia during the Crusades: The Integration of Cilician Armenians with the Latins (1080-1393), Oxford: Routledge, 2000.

Heyd, Wilhelm, Yakın-Doğu Ticaret Tarihi (Trans. in Turkish Enver Ziya Karal), Ankara: Türk Tarih Kurumu Publications, 1975.

Holt, Peter Malcolm, Haçlılar Çă̆ı, (Trans. in Turkish. Özden Arıkan), Istanbul: Tarih Vakfi Yurt Publications, 1999.

Kopraman, Kazım Yaşar, Makaleler, (ed. E. Semih Yalçın-Altan Çetin), Ankara: Berikan Publications, 2005.

Sevim, Ali, Anadolu’nun Fethi-Selçuklular Dönemi, Ankara: Türk Tarih Kurumu Publications, 2014.

Usta, Aydın, Haçlı Seferlerinde Kuşatma, Istanbul: Yeditepe Publications, 2015.

\section{Articles}

Aktan, Ali, "Memlûk-Haçlı Münasebetleri”, Belleten, p. 237, Ankara: Türk Tarih Kurumu, 1999, 411-452.

Altan, Ebru, “Kıbrıs Haçlı Krallığı (1191-1489)”, Türkler, vol. 6, Ankara: Yeni Turkiye Press, 2002, 1211-1220. 
Altan, Ebru, "Yafa", D. F. I. A, vol. 43, Istanbul: Turkish Diyanet Foundation, 2013, 171-174.

Amitai, Reuven, "The Conquest of Arsuf by Baybars: Political and Military Aspects", Mamluk Studies Review, vol. 9, No. 1, Chicago: Chicago University Pres, 2005, 61-83.

Çakar, Enver, "Haleb Sancagında Türkçe Yer Adları", OTAM, vol. 11, Ankara: Ankara University Press, 2000, 83-107.

Çavuşdere, Serdar, “Türklere Karşı Haçlı Donanma İttifakı Teşebbüsü ve İzmir Haçlı Seferi: 1341 - 1351", Journal of History School / Tarih Okulu Dergisi, Yıl / year 8, Say1 / Issue XXI, İzmir: Tarih Okulu Press, March 2015, 1-58.

Çetin, Altan, "Memlükler Devrinde Oguzlar/ Türkmenlere Bir Bakış" Osmanlı Araştırmaları, p. 33, İstanbul: İstanbul Univesity Press, 2009, 23-33.

Demirkent, Işın, "Haçlılar", D. F. I. A, vol. 14, Istanbul: Turkish Diyanet Foundation Publications, 1996, 525-546.

Humphreys, Stephen R, "Egypt in the World System of Later Middle Ages", in: The Cambridge History of Egypt, (ed. Carl F. Petry), Cambridge: Cambridge University Press, 2008, 445-462.

Kanat, Cüneyt, "Baybars Zamanında Memlûk-İlhanlı Münasebetleri”, Tarih Incelemeleri Dergisi, p. XVI, İzmir: Ege University Press, 2001, 34-45.

Kopraman, Kazım Yaşar, "Baybars I", D. F. I. A, vol. 5, Istanbul: Turkish Diyanet Foundation, 1992, 221-223.

Kopraman, Kazım Yaşar, "Memlûkler”, D. G. B. İ. T, vol. 6, Istanbul: Çă̆ Yayınları, 1992, 17-48.

Kopraman, Kazım Yaşar, “Memlûkler”, Türkler, vol. 6, Ankara: Yeni Türkiye Publications, 2002, 99-126.

Safran, Mustafa, "13. ve 14. Yüzyıllarda Karadeniz Limanlarının Ticarî ve Tarihi Önemi”, Ondokuz Mayıs Üniversitesi, Eğitim Fakültesi Birinci Tarih Boyunca Karadeniz Kongresi Bildirileri, Samsun: Ondokuz Mayıs University Press, 1988, 459-462.

Sahillioğlu, Halil, “Antakya”, D. F. I. A, vol. 3, Istanbul: Turkish Diyanet 
Foundation, 1991, 228-232.

Şeşen, Ramazan, "Selâhaddin-i Eyyûbî”, D. F. I. A, vol. 36, Istanbul: Turkish Diyanet Foundation, 2009, 337- 340.

Tahavī, Hatim Abd al-Rahman, "al-Șalibiyyun; Safahat min Naşat İktisadiyya”, İctihat, vol. 33, Dimask: Daru'l-İctihad, 1996, 89-128.

Tekindağ, Mehmed Cenab Şehabeddin, "Memlûk Tarihine Toplu Bakış", İ.Ü. Edebiyat Fakültesi Tarih Dergisi, p. 25, Istanbul: University Press, 1971, 1-38.

Turan, Osman, "Ortaçağlarda Türkiye-Kıbrıs Münasebetleri”, Selçuklular ve İslâmiyet, Istanbul: Boğaziçi Publications, 1993, 129-146.

Yiğit, Fatma Akkuş, "Memlûk - Ermeni Münâsebetleri”, Akademik Bakış, vol. 8, p. 16, Ankara: Hale Sivgin, 2015, 171-206.

Yiğit, İsmail, "Memlûkler”, Siyasî, Dini, Kültürel, Sosyal İslâm Tarihi, vol. 7, Istanbul: Kayıhan Publications, 1991, 1-424.

Ziyadah, Mohammad Mustafa, "The Mamluk Conquest of Cyprus in the Fifteenth Century", Bulletin of the Faculty of Arts, University of Egypt, vol. I, Part I, Cairo: Cairo University, 1933-1934, 90-113.

\section{Unpublish Phd Thesis}

Advan, Ahmad Muhammad Muhammad, al-Vadıa al-İktisadiyya fi Misr fi Asri'l- Mamlûkiyya al-'Ula, Cairo, 1972, 388-389. (Unpublished Phd Thesis).

Çavuşdere, Serdar, Marino Sanudo Torsello’nun XIV. Yüzyılın İlk Yarısında Ege'de Egemenlik Mücadelesi, 1291, 1353, Latinler, Denizci Türkmenler ve Haçlılar, Ankara University, History Department- Medieval History, 2014. (Unpublished Phd Thesis),

\section{Internet resources}

Polat, İbrahim Ethem, "Arap Edebiyatı Üzerinden Türk Tarihine Bir Bakış", available: http://www.ayk.gov.tr/wp-content/ uploads/2015/01/POLAT-\%C4\%B0brahim-Ethem-ARAP- 
EDEB\%C4\%B0YATI-\%C3\%9CZER\%C4\%B0NDEN-T\%C3\%9CRKTAR\%C4\%B0H\%C4\%B0NE-B\%C4\%B0R-BAKI\%C5\%9E. pdf(06.08.2017), (accessed: 6. 8. 2017)

Genç, Özlem, Korunur, Harun, “Antakya ’nın Haçlılar Tarafından Ele Geçirilişi”, Studies of Ottoman Domain (Electronic Journal), vol. 6, 2016, 59-82. available: http://www.thestudiesofottomandomain.com (accessed: 6. 8. 2017) 